\title{
Effects of Different Plant Extracts on Post-Thaw some Spermatological Parameters of Cryopreserved Awassi Rams Spermatozoa
}

\author{
Ilker YAVAS*1, Tugba KORKMAZ YAVAS² \\ ${ }^{1}$ Faculty of Veterinary Medicine, Department of Veterinary Clinicial Sciences, University of Mustafa \\ Kemal, Campus of Tayfur Sokmen, 31030 Antakya / Hatay Turkey \\ ${ }^{2}$ Control Laboratory Directorship of Hatay, Ministry of Food, Agriculture and Livestock, 4 M. Yanaray \\ street, 31030 Antakya / Hatay Turkey \\ *corresponding author, e-mail: iyavas@mku.edu.tr
}

Bulletin UASVM Animal Science and Biotechnologies 75(1)/ 2018

Print ISSN 1843-5262; Electronic ISSN 1843-536X

DOI:10.15835/buasvmcn-asb: 001617

\begin{abstract}
Several diluting-protecting media and different methods have been used for storage of ram semen in liquid and frozen state (Salamonand Maxwel, 2000). Addition of preservatives media for increasing storage of sperm are very important for successful artificial insemination in rams. This study was conducted on evaluate the effect of 3 plant extract. Ejaculates were collected using an electro-ejaculator twice a week during there productive season. After pooling, each pooled ejaculate was split into four equal aliquots and diluted with based Tris, Citric acid, Egg yolk, glicerol extender containing plant extracts $(0.02 \%$ and $\% 0.04$ Rosemary (Rosmarinus officinalis) (Rosemary extract -oil-soluble)); Echinacea (Echinacea purpurea) $(0.5 \mathrm{mg} / \mathrm{mL}$ and $1 \mathrm{mg} / \mathrm{ml}$ ) and St. John's wort (Herba Hyperici) $(0.5 \mathrm{mg} / \mathrm{mL}$ and $1 \mathrm{mg} / \mathrm{mL})$ at a final concentration of approximately $2 \times 10^{8}$ motil spermatozoa per straw. These results indicate that that the addition of Echinaceaand Rosemary as antioxidants have more positive effects for Awassi rams on spermatological parameters.
\end{abstract}

Keywords: plants, cryopreservation, Awassi rams

\section{INTRODUCTION}

The Awassi is the most numerous and widespread breed of sheep in south-west Asia (Figure 1). The processing and storage of ram semen reduce the motility and disrupt the membrane integrity of spermatozoa. It is generally assumed that these changes are detrimental and are associated with a loss of fertility capacity. Despite many years of empirical research that has established a variety of methods for the processing, storage and insemination of spermatozoa, fertility is generally lower after cervical insemination with stored than fresh semen (Maxwell, and Watson, 1996).

It has been shown that sperm quality during freeze-thawing process can be better maintained by addition of various antioxidants to semen extender compared to control (Bilodeau et al., 2001). There are limited document studying the effect of plant extracts as a antioxidants on sperm quality.

Ram sperm are extremely sensitive to oxidative stress due to the high content of unsaturated fatty acids present in the plasma membrane phospholipids in comparison to other species (Alvarez, and Storey, 1983; Alvarez et al., 1987). Many studies indicate that the quality of semen deteriorates during liquid storage for a long period (Kasimanickam et al., 2007). Seminal plasma confers some protection against ROS damage via glutathione (GSH), catalase (CAT), glutathione peroxidase (GSH-Px) and superoxide-dismutase 


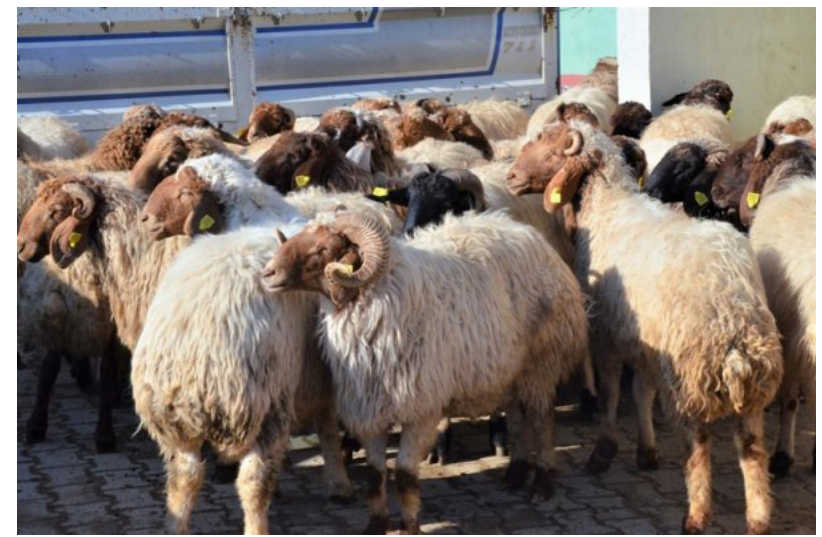

Figure 1. Awassi Rams

(SOD) (Hammadeh et al., 2009). Nonetheless, the protective role of the seminal plasma is reduced after applying several dilutions for semen storage (Martínez-Páramo et al., 2009). To cope with such problems, different antioxidants have extensively been added to the extenders to improve ram sperm quality (Bucak, and Tekin, 2007). Different natural herbs have been studied for the several antioxidant properties. These herbs contain many phytochemicals (carotenoids, polyphenol, flavonoids) widely used in cosmetic, pharmaceutic and food industry with beneficial effects (Zheng, and Wang, 2001). Recently, there has been a global trend concerning natural antioxidants that are present in fruits, vegetables, plants, oil seeds, and herbs to preserve semen quality (Del Valle et al., 2013; Motlaghet et al., 2014).

Therefore, the present study was conducted to determine the effects of some plants added to extender of Awassi rams semen on some spermatological parameters aftert hawing of cryopreserved semen.

\section{MATERIALS AND METHODS.}

\section{Reagents}

Unless otherwise stated, reagents were purchased from Sigma Chemical Company (St. Louis, MO, USA). Plant extracts were purchased from Immu-Nat Herbal Medicine and Natural Health Products (Mugla, Turkey).

\section{Semen Collection and Evaulation}

Ejaculate samples obtained from three maturea was rams in this study. Ejaculates were collected using an electro-ejaculator twice a week during there productive season. After pooling, each poole dejaculate was split into four equa laliquots and diluted with based Tris, Citricacid, Egg yolk, glicerol extender containing plant exratcts $(0.02 \%$ and $0.04 \%$ Rosemary (Rosmarinus officinalis) ( Rosemary extract -oil-soluble); Echinacea (Echinacea purpurea) $(0.5 \mathrm{mg} / \mathrm{mL}$ and $1 \mathrm{mg} / \mathrm{mL})$ and St. John's wort (Herba Hyperici) $(0.5 \mathrm{mg} /$ $\mathrm{mL}$ and $1 \mathrm{mg} / \mathrm{mL}$ ) at a final concentration of approximately $2 \times 10^{8}$ motil spermatozoa per straw. Sperm motility was determined subjectively using light microscope (Olympus, Japan) at 400 magnification. Sperm density was determined according to the haemacytometric method. For this aim, sperm was diluted at ratio of 1:500 with Hayem solution $\left(5 \mathrm{~g} \mathrm{Na}_{2} \mathrm{SO}_{4}, 1 \mathrm{~g} \mathrm{NaCl}, 0.5 \mathrm{~g}\right.$ $\mathrm{HgCl}_{2}, 200 \mathrm{ml}$ bicine) and density was determined using a $100 \mathrm{ml}$ Thomahaemocytometer (TH-100, Hecht-Assistent, Sondheim, Germany) at $400 \mathrm{x}$ magnification with Olympus BX50 phase contrast microscope (Olympus, Japan) and expressed as spermatozoa $10^{9} / \mathrm{ml}$. Sperm counting chambers were alway skept in a moistatmosphere for at least $10 \mathrm{~min}$. Before cell counting. Sperm pH was measured using indicator papers (Merck, 5.5-9) within $30 \mathrm{~min}$ of sampling. To assess live/dead sperm percentage, eosin-nigrosin preparations were made according to the method noted by Björndahl et al., (2003). Totally 300 sperm cells were counted on each slide at $1000 \mathrm{x}$ magnification. Spermatozoa with abnormal morphology were assessed by the Hancock's solution (HS) (HS: $62.5 \mathrm{ml}$ formalin, $150 \mathrm{ml}$ sodium saline solution, $150 \mathrm{ml}$ buffer solution, and $500 \mathrm{ml}$ double-distilled water). For this assessment, three drops of semen suspension were mixed with $1 \mathrm{ml}$ HS. Afterward, one drop of this mixture was placed on a slide and mounted with a coverslip. The percent of abnormal spermatozoa was recorded by counting 200 spermatozoa under phase contrast microscopy at $1000 \mathrm{x}$. The hypo-osmotic swelling (HOS) test was 
Table 1. Effect of plants on post-thawmotility, viability, abnormal rates of cryopreserved Awassi ram semen

\begin{tabular}{cccccc}
\hline Plants & $\begin{array}{c}\text { Plants } \\
\text { Concentrations }\end{array}$ & $\begin{array}{c}\text { Post-thaw Motility } \\
(\%) \pm \text { S.D. }\end{array}$ & $\begin{array}{c}\text { Viabile Cells } \\
(\%) \pm \text { S.D. }\end{array}$ & $\begin{array}{c}\text { Abnormal Rates } \\
(\%) \pm \text { S.D. }\end{array}$ & $\begin{array}{c}\text { Host } \\
(\%) \pm \text { S.D. }\end{array}$ \\
\hline Echinacea & $0.5 \mathrm{mg} / \mathrm{mL}$ & $53.7 \pm 3.7^{\mathrm{a}}$ & $48.1 \pm 1.6^{\mathrm{a}}$ & $23.4 \pm 1.3^{\mathrm{a}}$ & $40.5 \pm 1.3^{\mathrm{a}}$ \\
\hline Rosemary & $1 \mathrm{mg} / \mathrm{mL}$ & $50.2 \pm 2.3^{\mathrm{a}}$ & $59.2 \pm 1.3^{\mathrm{b}}$ & $22.3 \pm 1.4^{\mathrm{a}}$ & $31.3 \pm 2.7^{\mathrm{b}}$ \\
\hline St. John's wort & $0.02 \%$ & $48.2 \pm 1.4^{\mathrm{b}}$ & $56.2 \pm 1.4^{\mathrm{b}}$ & $23.8 \pm 1.2^{\mathrm{a}}$ & $38.0 \pm 1.4^{\mathrm{a}}$ \\
\hline & $0.04 \%$ & $43.2 \pm 1.1^{\mathrm{c}}$ & $59.6 \pm 1.5^{\mathrm{b}}$ & $25.6 \pm 1.5^{\mathrm{a}}$ & $32.5 \pm 1.7^{\mathrm{b}}$ \\
\hline Control & $1 \mathrm{mg} / \mathrm{mL}$ & $33.6 \pm 1.6^{\mathrm{d}}$ & $68.2 \pm 3.4^{\mathrm{c}}$ & $24.6 \pm 1.2^{\mathrm{a}}$ & $29.6 \pm 2.1^{\mathrm{b}}$ \\
\hline
\end{tabular}

used to evaluate the functional plasma membrane of spermatozoa as described by Revell and Mrode (1994). Briefly, $10 \mu \mathrm{l}$ semen were incubated with $100 \mu \mathrm{l}$ hypo-osmotic solution $(9 \mathrm{~g} / \mathrm{l}$ fructose and $4.9 \mathrm{~g} / \mathrm{l}$ sodium citrate, $100 \mathrm{~m} \mathrm{Osm} / \mathrm{kg}$ ) at $37^{\circ} \mathrm{C}$ for $60 \mathrm{~min}$. Afterward, $0.1 \mathrm{ml}$ of the mixture was placed on a microscope slide and mounted with a coverslip. A total of 400 spermatozoa were evaluated and sperm with swollen and coiled tails were determined in each sample under phasecontrast microscopy at $400 \mathrm{x}$.

\section{Statistical Analysis}

Results are presented as mean \pm SE. Data for percentage of sperm motility and fertilization were transformed by angular transformation prior to statistical analysis by SPSS 22.0 software. Differences between parameters were analyzed by repeated analysis of variance (ANOVA). Significant means were subjected to a multiple comparison test (Duncan) at level of $\alpha=0.05$.

\section{RESULTS AND DISCUSSIONS}

Post-thawed spermatozoa motility had significant difference at the groups with plants Echinacea $(0,5 \mathrm{mg}) 53,7 \pm 3,7 \%$ and rosemary $(0,02 \%) 48,2 \pm 1,2 \%$, compared to the control $(36,5 \pm 2,1 \%)$. At abnornal spermatozoarates, while there was not statistically difference among the groups. Dead spermatoza with the lowest rate was attained at group with Echinacea. (0,5 mg) At Host, Echinacea and rosemary gave the highes trates $(40,5 \pm 2,7 \%$ and $38,0 \pm 1,4 \%, \mathrm{P}<0,05)$, statistically (Table 1 ).
In this study Echinacea, rosemary and st. john's wort extracts were used for inhibiting detrimental effects of freeze-thawing process on ram semen. The results of the present study demonstrated that treatment with Echinaceaandrosemary extract can efficiently change the total and motility, viability, and membrane integrity. Our result about motility agree with the result of other studies Malo et al., (2011) and Zhao et al., (2009).

\section{CONCLUSIONS}

In conlusion, it was seen that some plant extract (Echinacea and rosemary) added to extender of Awassi rams semen provided the significant contributions on post-thawing somes permatological parameters.

\section{REFERENCES}

1. Alvarez JG, Storey BT (1983). Taurine, hypotaurine, epinephrine andalbumin inhibit lipid peroxidation in rabbit spermatozoa and protect against loss of motility. Biology of Reproduction, 29: 548-555.

2. Alvarez JG, Touchstone JC, Blasco L, Storey BT (1987). Spontaneous lipid peroxidation and production of hydrogen peroxide and superoxide in human spermatozoa. Superoxide dismutase as major enzyme protectant against oxygen toxicity. Journal of Andrology, 8: 338-348.

3. Björndahl L, Söderlund I, Kvist U (2003). Evaluation of the one-step eosin-nigrosin staining technique for human sperm vitality assessment, Human Reproduction, 18: 813-816.

4. Bilodeau JFS, Blanchette C, Gagnon MA (2001). Sirard Thiols prevent $\mathrm{H}_{2} \mathrm{O}_{2}$-mediated loss of sperm motility in cryopreserved bull semen. Theriogenology, 56: 275-286.

5. Bucak MN, Tekin N (2007). Protective effect of taurine, glutathione and trehalose on the liquid storage of ram semen. Small Ruminant Research, 73: 103-108. 
6. Del Valle I, Souter A, Maxwell WMC, Muino-Blanco T, Cebrián-Pérez JA (2013). Function of ram spermatozoa frozen in diluents supplemented with casein and vegetable oils. Animal Reproduction Science, 138: 213-219.

7. Hammadeh ME, Filippos A, Hamad MF (2009). Reactive oxygen species and antioxidant in seminal plasma and their impact on male fertility, International Journal of Fertility \& Sterility, 3: 87-110.

8. Kasimanickam R, Kasimanickam V, Pelzer KD, Dascanio JJ (2007). Effect of breed and sperm concentration on the changes instructural: functional and motility parameters of ram-lamb spermatozoa during storage at $4^{\circ} \mathrm{C}$. Animal Reproduction Science, 101: 60-73.

9. Martínez-Páramo S, Martínez-Pastor F, MartínezRodríguez G, Herráez MP, Cabrita E (2009). Antioxidant status in fresh and cryopreserved sperm from gilthead sea bream (Sparusaurata). In:The 2nd International Workshop on Biology of Fish Gametes, 8-12 September, Valencia, Spain.

10. Malo C, Gil L, Cano R, Martinez F, Gale I (2011). Antioxidant effect of rosemary (Rosmarinus officinalis) on boar epididymal spermatozoa during cryopreservation. Theriogenology, 75: 1735-174.
11. Maxwell WMC, Watson PF (1996). Recent progress in the preservation of ram semen. Animal Reproduction Science, 42: 55-65.

12. Motlagh MK, Sharafi M, Zhandi M, MohammadiSangcheshmeh A, Shakeri M, Soleimani M, Zeinoaldini S (2014). Antioxidant effect of rosemary (Rosmarinus officinalis L.) extract in soybean lecithin-based semen extender following freeze-thawing process of ram sperm, Cryobiology 69: 217-222.

13. Salamon S, Maxwell WMC (2000). Storage of Ram Semen. Animal Reproduction Science 62: 77-111.

14. Revell SG, Mrode RA (1994). An osmotic resistance test for bovine semen. Animal Reproduction Science, 36: 7786

15. Zhao HW, Li QW, Ning GZ, Han ZS, Jiang ZI, Duan YF (2009). Rhodiola sacra aqueous extract (RSAE) improves biochemical and sperm characteristics in cryopreserved boar semen. Theriogenology, 71: 849-57.

16. Zheng W, Wang SY (2001). Antioxidant activity and phenolic compounds in selected herbs Journal of Agricultural and Food chemistry, 49: 5165-5170. 